\title{
Magdalena Ziętek-Wielomska
}

\section{Podróż płci w nieznane \\ Rozważania na marginesie teorii modernizacji Rolfa Petera Sieferlego}

\section{Sformułowanie problemu}

Cecha charakterystyczna wszystkich cywilizacji sprzed epoki modernizacji jest przekonanie o istnieniu obiektywnego, naturalnego porządku rzeczy, którego człowiek swoją wolą zmienić nie może. U podłoża procesów modernizacyjnych leży natomiast przekonanie, że człowiek jest „panem form” - wszystkie elementy wcześniejszego porzadku, przez pokolenia postrzeganego jako naturalny, podlegaja zakwestionowaniu. Cechą charakterystyczna tych procesów jest zatem rewolucyjność. Rewolucja obaliła zastany hierarchiczny porządek feudalny, stworzyła fabryki, burżuazje i proletariat po to, aby w następnym etapie stworzyć społeczeństwo masowe, państwo opiekuńcze, a w końcu agendę progresywistyczna.

Magdalena Ziętek-Wielomska - prawnik, filozof, prezes fundacji Instytut Badawczy Pro Vita Bona. Była stypendystka Fundacji Konrada Adenauera (KAS), Deutscher Akademischer Austauschdienst (DAAD) i Gemeinschaft für studentischen Austausch in Mittel- und Osteuropa e.V. (GFPS). Pracowała w Rheinisch-Westfälische Technische Hochschule (RWTH) Aachen w Akwizgranie oraz Europejskim Uniwersytecie Viadrina we Frankfurcie nad Odrą. Członek redakcji czasopisma naukowego „Pro Fide, Rege et Lege”. W swojej pracy naukowej i publicystycznej zajmuje się filozofia prawa, cybernetyką społeczna oraz propagowaniem klasycznej koncepcji dobrego życia. 
Proces rewolucyjny objął także kwestię ról społecznych, przede wszystkim w formie ruchu emancypacji kobiet. Następnie, dzięki postępowi technicznemu, człowiek uzyskał możliwość ingerowania w swoja płeć biologiczna poprzez jej zmianę. Płciowość stała się więc domena ludzkiej dyspozycji. Proces modernizacji społecznej wyszedł wszelako poza kwestię zmiany płci i zanegował koncepcję dwupłciowości jako takiej. Teorie gender wprowadziły pojęcie płci kulturowej (gender), która może, ale nie musi, być powiązana $z$ płcią biologiczna (sex). Natomiast teorie queer radykalnie zanegowały twierdzenie, że tożsamości (czy też orientacje) seksualne istnieją obiektywnie i sa zwiąane $z$ ludzka naturą.

Pierwsza faza modernizacji charakteryzowała się daleko posuniętym optymizmem w kwestii możliwości kształtowania nowego porządku społecznego. Liberalne instytucje były traktowane jako absolutny fundament, na którym miało powstać dobrze urządzone społeczeństwo ludzi wolnych. Dość szybko jednak się okazało, że transformacja społeczna i industrializacja oznaczaja nie tylko postęp i dobrobyt, ale także biedę, wyzysk i ludzką krzywdę. Nieodłącznym elementem procesu transformacji stało się więc doświadczenie kryzysu - socjalnego, ekonomicznego, ekologicznego, politycznego itd.

Należy postawić pytanie, czy tak zwana rewolucja genderowa spowoduje kolejny kryzys, który tym razem dotknie człowieka w obrębie jego psyche? Główna kwestia dotyczy tego, czy człowiek może rzeczywiście w sposób tak fundamentalny zanegować ideę naturalnego porządku, czyli porządku wynikającego $z$ praw rządzących natura, jak to nie raz uczynił w procesie modernizacji? Czy kolejne etapy rewolucji i powodowanych przez nia kryzysów ostatecznie doprowadza człowieka do pogodzenia się $z$ idea, że jednak ludzka natura wyznacza obiektywne zasady porzadku społecznego, które człowiek musi uszanować, jeśli nie chce doprowadzić samego siebie i swojego otoczenia do samozniszczenia?

Próba udzielenia całościowej odpowiedzi na te pytania nie jest możliwa w ramach tego opracowania. W niniejszym tekście problematyka tak zwanej rewolucji genderowej zostanie przedstawio- 
na w świetle koncepcji modernizacji niemieckiego historyka Rolfa Petera Sieferlego. Jego przemyślenia moga bowiem dostarczyć pewnych argumentów przemawiających na rzecz tezy, że człowiek jest częścia natury oraz że ma to określone implikacje także na poziomie kultury.

\section{Transformacja spoleczna jako proces społecznej mobilizacji}

\section{Trzy reżimy metabolizmu społecznego według Sieferlego}

Zdaniem Rolfa Petera Sieferlego znajdujemy się w procesie transformacji: przejścia do nowej cywilizacji, której ostatecznej formy wciąż nie znamy. Punktem wyjścia tego procesu jest forma społeczna cywilizacji agrarnych, które kilka tysięcy lat temu rozwinęły się po epoce cywilizacji myśliwych i zbieraczy.

Swoja periodyzacje historii człowieka Sieferle przeprowadza na podstawie teorii metabolizmu społecznego. Metabolizm społeczny to forma, która przyjmuje przemiana materii między społeczeństwem i jego otoczeniem fizycznym ${ }^{1}$. Metabolizm, a więc przemiana materii, obejmuje cały obszar produkcji, konsumpcji, techniki oraz przemieszczania się ludności, i ostatecznie jest uwarunkowany ilościa energii dostępnej w systemie. Przyjmując tak zdefiniowane kryterium metabolizmu społecznego, Sieferle wyróżnił trzy formy reżimów społecznych. Pierwszy - to społeczeństwa myśliwych i zbieraczy, których baza energetyczna opierała się na niekontrolowanych przepływach energii słonecznej. Następny - to społeczeństwa agrarne, które kontrolowały przepływy energii słonecznej. Trzeci - to reżim społeczeństwa industrialnego (przemysłowego), czyli energetycznie opierającego się na paliwach kopalnych ${ }^{2}$.

1 R.P. Sieferle, Der europäische Sonderweg. Ursachen und Faktoren, Breuninger Stiftung, Stuttgart 2003, s. 17.

2 Ibidem. 
Pierwszy typ cywilizacji był oparty na zbieractwie i myślistwie oraz charakteryzował się nomadycznym trybem życia. Według Sieferlego społeczności rolnicze pojawiły się około 10 tys. lat temu, ale dopiero mniej więcej 5 tys. lat temu stały się formą dominująca. Społeczeństwa myśliwsko-zbieracze funkcjonuja do dzisiaj wyłącznie w niszach wśród plemion pierwotnych ${ }^{3}$. Świat, który znamy stworzyła natomiast cywilizacja rolnicza ${ }^{4}$. Jego podstawa sa ziemia i energia słoneczna. Poprzez fotosyntezę energia słoneczna jest przejmowana przez rośliny, a następnie chemicznie przez nie przetwarzana, po czym zostaje wtórnie przetworzona przez zwierzęta i ostatecznie doprowadzona do formy, która może być używana przez człowieka. Istoty żywe - rośliny i zwierzęta - są zatem używane przez człowieka jako konwektory energetyczne: jako pożywienie, jako narzedzia pracy, jako materiały budowlane, jako paliwa, jako środek transportu. Dla cywilizacji agrarnych charakterystyczne jest więc to, że człowiek próbuje przejać jak największą kontrolę nad procesami życiowymi poprzez wycinanie lasów, zakładanie pól i łąk, sadzenie roślin, nawadnianie i drenowanie gruntów, spalanie drewna i budowanie $z$ niego, hodowanie i zabijanie zwierzat, ochronę swojego inwentarza, zwalczanie szkodników, chwastów i drapieżników ${ }^{5}$. Cywilizacja agrarna siłą rzeczy ma charakter stacjonarny oraz nie jest w stanie rozwijać się ponad pewien poziom ${ }^{6}$.

Sieferle pokazuje, że tylko jedna jedyna cywilizacja rolnicza wyrwała się $z$ ogólnego wzorca agrarnego sposobu produkcji i wygenerowała nowy wzorzec. Proces ten rozpoczą się ponad dwieście lat temu w Wielkiej Brytanii, a następnie, w XIX wieku, został przeniesiony na pozostałe państwa Europy Zachodniej, Ameryki Północnej i Australii. Wygenerował on nowy typ społeczeństwa, który jest określany na wiele sposobów: społeczeństwo nowoczesne, przemysłowe, kapitalistyczne. Sieferle nazywa je społe-

\footnotetext{
3 Ibidem, s. 8.

4 R.P. Sieferle i in., Das Ende der Fläche. Zum gesellschaftlichen Stoffwechsel der Industrialisierung, Böhlau, Köln 2006, s. 7 i nast.

5 Ibidem, s. 22 i nast.

6 Ibidem, s. 332 i nast.
} 
czeństwem znajdujacym się $\mathrm{w}$ procesie transformacji. Jego cecha charakterystyczna jest to, że nie znosi żadnych innych form społecznych obok siebie, dokonuje wobec nich ekspansji i wchłania w swoje struktury ${ }^{7}$. Forma ta, gdziekolwiek konfrontuje się $z$ innymi kulturami, „traktuje je jako stadium przejściowe do własnej kultury albo jako przypadek szczególny, jako pomnik kultury lub atawizm, po to, aby je ostatecznie potraktować jako folklor i w ten sposób zintegrować"8. Źródło jej sukcesów kryje się w jej ewolucyjnej przewadze, reprezentuje bowiem wyższy poziom kompleksowości, większe możliwości techniczne, zdolność do autorefleksji, a wreszcie - możliwości regulowania otoczenia i penetracji władzy. Nowa forma społeczna potrafi dość skutecznie rozwiąać problemy związane $z$ zaspokajaniem podstawowych potrzeb ludzkich, do których należą przede wszystkim zwalczanie chorób, dostarczanie żywności, stabilizacja porządków politycznych, zapewnienie indywidualnej wolności. Na tym też polega jej wysoka atrakcyjność dla członków innych kultur, które ostatecznie rzadko potrafią się jej oprzeć. Sieferle stwierdza, że sama Europa w największym stopniu oddaliła się od swoich własnych korzeni stworzonych w cywilizacji agrarnej ${ }^{9}$. Ostateczne kontury tej nowej formy cywilizacyjnej do dzisiaj jednak się nie wykrystalizowały, gdyż ciagle znajdujemy się w procesie transformacji, który w dużej mierze jest opisywany w negatywny sposób, jako zanegowanie wcześniejszych struktur ${ }^{10}$. Transformacja reżimu metabolizmu społecznego postrzegana jest bowiem nie tylko jako industrializacja, ale także jako mobilizacja feudalnej struktury społecznej, jako rozluźnienie i rozpad tradycyjnych religijnych systemów religijnych oraz światopoglądowych czy też jako mentalny proces emancypacji indywidualnej ${ }^{11}$.

\footnotetext{
7 R.P. Sieferle, Der europäische Sonderweg..., s. 7.

8 Ibidem, s. 8.

9 Ibidem, s. 9.

${ }^{10}$ Ibidem, s. 15.

${ }^{11}$ Ibidem, s. 27.
} 


\section{Cywilizacja agrarna i jej stosunek do natury}

Każda $z$ trzech form reżimów metabolizmu społecznego wytworzyła właściwa dla siebie „nadbudowę społeczna”.

Sieferle pokazuje, że wszystkie cywilizacje agrarne stworzyły pewne wspólne metody organizacji życia zbiorowego. W przeciwieństwie do prostych społeczności rolniczych cywilizacje agrarne były silnie zhierarchizowane społecznie, miały rozwinięty system podziału pracy, wykształciły miasta, rzemiosło i wyższą kulturę. Większość ludności (80-90 proc.) stanowili chłopi, którzy byli rozproszeni po całym terytorium państwa i mieli bardzo ograniczony kontakt $z$ aparatem kultury wyższej ${ }^{12}$. Kulturę wyższą rozwijały dwie rządzące warstwy społeczne, do których należeli wojownicy, rządzący panowie, właściciele ziemscy oraz kapłani i uczeni ${ }^{13}$.

Światopogląd właściwy dla cywilizacji agrarnych miał wiele elementów wspólnych. Zakładał podporządkowanie człowieka światu rządzonemu przez Boga (czy też bogów), który (którzy) sprawował (sprawowali) kontrolę nad natura i człowiekiem. Porządek społeczny wykształcony w cywilizacjach agrarnych bez watpienia daje sie opisać jako porzadek organiczny. Człowiek był we wszystkich obszarach swojego życia podporządkowany ograniczeniom, które wynikały wprost $z$ natury. Jego cykl życia był regulowany przez pory roku i dnia - chłop wstawał wraz ze wschodem słońca i kładł się spać o zachodzie itd. Człowiek miał poczucie, że podlega pewnym obiektywnym prawidłowościom, na których kształt nie ma żadnego wpływu i musi się im po prostu podporządkować. Źródła praw i obowiąków upatrywano $\mathrm{w}$ tradycji. $\mathrm{U}$ ich podstawy leżały przekonania religijne, które same stanowiły część tradycji danej wspólnoty politycznej.

Sieferle opisuje obraz świata charakterystyczny dla chrześcijańskiej Europy jako natura lapsa. Model ten był ściśle związany $z$ właściwym dla europejskiego średniowiecza przekonaniem o skażeniu natury przez grzech pierworodny, a więc natury upadłej.

12 Ibidem, s. 22.

${ }^{13}$ Ibidem, s. 23. 
Obraz ten zakładał hierarchiczna strukturę bytów: od tych najbardziej doskonałych do mniej doskonałych ${ }^{14}$. Według koncepcji natura lapsa przyroda nie ma żadnych wewnętrznych regularności, tendencji do spontanicznego stanu równowagi, natomiast zachowanie porządku naturalnego leży wyłącznie w gestii Boga. Gdyby Bóg zechciał, natura mogłaby ulec zupełnemu rozpadowi.

$\mathrm{Na}$ gruncie codziennego obcowania $\mathrm{z}$ natura $\mathrm{w}$ cywilizacjach agrarnych obowiazywała zasada zrównoważonego rozwoju. W swojej działalności człowiek musiał w taki sposób gospodarować ziemia i zasobami naturalnymi, żeby mu starczyły na długie lata. Doprowadzenie do erozji ziemi czy też wyrąbanie wszystkich lasów w okolicy mogły doprowadzić do klęski głodu i braku surowców naturalnych $\mathrm{w}$ następnych latach. Człowiek codziennie był zatem konfrontowany $z$ problemem ograniczoności ilości dostępnych dóbr i musiał nimi umiejętnie oraz roztropnie gospodarować.

\section{Transformacja spoleczna jako proces mobilizowania zasobów naturalnych i ludzkich}

Cywilizacje agrarne wykształciły zatem swoisty obraz swiata i wynikające $z$ tego koncepcje społeczne. Ich założenia były stopniowo poddawane krytyce już od wczesnej nowożytności, ale dopiero od momentu przebudowy energetycznej podstawy życia społecznego, która umożliwiła człowiekowi daleko posunięte kreowanie swojej rzeczywistości, nowe koncepcje mogły zacząć realnie kształtować stosunki społeczne.

Sieferle podkreśla, że nie byłoby tych wszystkich procesów emancypacyjnych, gdyby uprzednio nie zaszły procesy przemiany reżimu socjometabolicznego, które wymusiły określone zmiany w „nadbudowie społecznej”. Uważa, że jeśli proces transformacji opisuje się za pomoca pojęć fizyczno-energetycznych, zyskuje on na jednoznaczności. Staje się widoczne, że chodziło o fundamen-

\footnotetext{
${ }_{14}$ R.P. Sieferle, Die Krise der menschlichen Natur: zur Geschichte eines Konzepts, Suhrkamp, Frankfurt am Main 1989, s. 14 i nast.
} 
talną zmianę stosunku społeczeństwa do jego naturalnego środowiska, co stworzyło nowe możliwości, aby konkretne innowacje społeczne, kulturowe i polityczne, które się pojawiały już w społeczeństwach agrarnych, stały się dominujące ${ }^{15}$. Zdaniem Sieferlego koniecznym warunkiem fizycznym dla procesu transformacji było przezwyciężenie energetycznych ograniczeń systemów agrarnych, co stało się możliwe poprzez odkrycie nowych technik przetwarzania paliw kopalnianych. Historyk wskazuje więc na podstawowa rolę, jaką odegrało wyłonienie się nowego reżimu socjometabolicznego na przełomie XVIII i XIX wieku ${ }^{16}$. Bez wykorzystania nowych źródeł energii europejskie społeczeństwa XIX i XX wieku pozostałyby systemami rolniczymi ${ }^{17}$.

Sieferle podkreśla, że $z$ pespektywy ekonomiczno-ekologicznej proces industrializacji, który zachodził w ciągu ostatnich dwustu lat, stanowi historyczna jedność dwóch procesów. Na płaszczyźnie fizycznej chodziło o przejście do systemu energetycznego opartego na paliwach kopalnych, uzyskanie dostępu do wielkich zasobów energetycznych, które zostały zmobilizowane i zaczęły napędzać materialne procesy przemiany materii. Na płaszczyźnie społecznej chodziło o wzrost produktywności poprzez innowacje techniczne i organizacyjne, które były ściśle powiązane ze zmianami zachodzacymi w całym kompleksie takich instytucji jak handel, transport, finanse, edukacja, infrastruktura, nauka, stosunki polityczne, prawo itd. ${ }^{18}$. Warunkiem przeprowadzenia industrializacji było zatem całkowite przegrupowanie sił i instytucji społecznych: „Dosłownie wszystko zostało zmobilizowane. Ludzie, materiały, ostatecznie także większe ekosystemy zostały ruszone $z$ posad"19.

\footnotetext{
${ }^{15}$ R.P. Sieferle, Der europäische Sonderweg..., s. 30.

${ }^{16}$ Ibidem, s. 31.

${ }^{17}$ Sieferle zastrzega, że podkreślanie roli ekologicznych i energetycznych warunków zmian społecznych nie może być rozumiane jako naturalistyczny redukcjonizm. Żeby wystapił pewien efekt, musza się spotkać dwa elementy. Po pierwsze, muszą to być określone zasoby naturalne, materiał albo nośnik energii oraz procedura ich używania, a także określone urządzenia techniczne. $Z$ drugiej strony musza wystapić: zapotrzebowanie społeczne, akceptacja kulturowa, struktura ekonomiczna oraz polityczne warunki ramowe. Ibidem, s. 31.

${ }^{18}$ Ibidem, s. 32.

${ }^{19}$ Ibidem, s. 39.
} 
Prawdopodobnie żaden obszar życia nie ostał się przed fundamentalnym przewrotem, który spowodowały procesy industrializacji i modernizacji. Jednym $z$ aspektów tego „przewrotu” były procesy indywidualnej emancypacji, czyli pojawienie się autonomicznego indywiduum, które swoja tożsamość definiuje nie poprzez przynależność do określonej grupy, tylko refleksyjnie samo się projektuje. Autonomiczne indywiduum uwolniło się od tradycyjnych związków i zaczęło samodzielnie tworzyć związki społeczne według własnego wyboru ${ }^{20}$. Elementem tak rozumianej emancypacji był rozpad tradycyjnych systemów religijnych oraz innych tradycyjnych schematów intepretowania rzeczywistości. W ich miejsce wkroczyło dażenie do opanowania przyrody poprzez technikę i naukę ${ }^{21}$. W sferze gospodarczej „przewrót” polegał na zastapieniu wcześniejszej koncentracji na produkcji podstawowej (czyli rolnictwa, rybactwa i górnictwa) przez nowoczesna działalność gospodarczą ${ }^{22}$. W sferze politycznej był to proces demokratyzacji, w którym wcześniejsze autorytarne i personalne formy władzy zostały zastapione przez

\footnotetext{
${ }^{20}$ Ibidem, s. 27-28.

${ }^{21}$ Ten wątek jest blisko spowinowacony $\mathrm{z}$ wizja państwa przedstawiona przez Francisa $\mathrm{Ba}-$ cona w powieści Nowa Atlantyda. Zgodnie $z$ tą wizja państwo ma stać na straży postępu naukowego, technicznego i społecznego. F. Bacon, Nowa Atlantyda i Z Wielkiej Odnowy, przeł. J. Kornatowski, Wydawnictwo Alfa-Wero, Warszawa 1995, passim. W słowie wstępnym do polskiego wydania powieści Jerzy Szacki stwierdza, że jest to utwór bezcenny dla zrozumienia kultury, do której powstania Bacon przyczynił się jak mało kto: „Kultury, której podstawa jest wiara w nieograniczone możliwości nauki i techniki i szansę ich pełnego wykorzystania dla dobra ludzkości. Kultury, która nazywa się zwykle kultura nowoczesna. [...] Utopia Bacona traktuje mianowicie nie tyle o tym, jak dzięki reorganizacji stosunków społecznych lepiej wykorzystać możliwości dane ludziom przez naturę, ile o tym, jak zbiorowym wysiłkiem te możliwości pomnażać, wydzierając naturze jej tajemnice i zwiększając ludzką nad nią władzę. Ten sposób myślenia był wśród dawnych utopistów zgoła wyjątkowy i zatriumfował dopiero w XIX wieku, przynoszącym dojrzałe owoce rewolucji przemysłowej. [...] Najważniejsze i naprawdę oryginalne strony Nowej Atlantydy to opis Domu Salomona. [...] Ów Dom Salomona to potężna instytucja, jakiej nie ma w innych utopiach, jeśli nawet ich autorzy przykładali do nauki wielką wagę. Instytucja, będąca ni to zakonem, ni to akademią nauk, ni to, jak mówi się w dzisiejszym żargonie, systemem placówek badawczo-rozwojowych. Jej celem jest "zgłębianie stosunków, zmian i sił wewnętrznych natury, tudzież rozszerzanie - jak tylko to będzie możliwe - granic władztwa ludzkiego nad nią". Można powiedzieć, iż celem Domu Salomona jest urzeczywistnianie takiej koncepcji nauki, jaka znajdujemy $\mathrm{w}$ innych pismach Bacona. Chodzi o zorganizowanie na wielka skale procesu pomnażania wiedzy, służącej zaspokajaniu praktycznych ludzkich potrzeb".

${ }^{22}$ R.P. Sieferle, Der europäische Sonderweg..., s. 28.
} 
partycypację polityczna mas. Demokracja parlamentarna, państwo prawa, konstytucja $z$ katalogiem praw człowieka stały się politycznym wyrazem emancypacji i autonomizacji jednostki ${ }^{23}$.

\section{Rewolucja totalna}

\section{Autonomia jako podstawa rewolucji podmiotu}

Zarysowany skrótowo proces transformacji charakteryzuje się coraz większym wyemancypowaniem człowieka ze struktur świata stworzonego w czasie trwania epoki cywilizacji agrarnych, dla której charakterystyczna była wiara $\mathrm{w}$ istnienie obiektywnych praw natury, do których człowiek musi się dostosować.

Cecha charakterystyczna procesu transformacji jest podważanie coraz to kolejnych obszarów ludzkich przekonań w kwestii tego, co rzekomo jest naturalne. W pierwszej kolejności były to „naturalne" metody produkcji, oparte na gospodarowaniu ziemia i jej płodami. Konieczność mobilizacji zasobów ludzkich w celu przestawienia produkcji na przemysłowo-kapitalistyczna była zwiąana $z$ podważeniem feudalnego, hierarchicznego i organicznego porządku społecznego, który przez wielu obrońców starego świata był postrzegany jako „naturalny”. Podważeniu ludzkich wyobrażeń na temat „naturalnej” hierarchii społecznej towarzyszył proces emancypacji - nie tylko prawnej, ale także politycznej - szerokich mas społecznych. Związana była ona głównie $z$ ruchem robotniczym, który postulował dopuszczenie do władzy przedstawicieli klasy proletariackiej. Kolejnym etapem rewolucji była emancypacja kobiet i przedefiniowanie kategorii „naturalnych” ról w obrębie rodziny. Rewolucja genderowa jest prawdopodobnie najnowszym etapem procesu transformacji.

Istota wszystkich procesów rewolucyjnych składających się na proces transformacji jest ich osadzenie w ramach kategorii ludz-

${ }^{23}$ Ibidem, s. 28. 
kiej autonomii, dlatego można mówić o rewolucji podmiotu ${ }^{24}$. Istota zwłaszcza powojennej fali rewolucji stało się odrzucenie wszelkich norm społecznych niebędących efektem wspólnego uzgodnienia jako narzucanych podmiotom, czyli opresyjnych ${ }^{25}$. U podstaw najnowszego etapu rewolucji podmiotu legł postulat, aby jednostka sama decydowała o wyznawanych przez siebie wartościach, ideale udanego życia, szczęścia itp. Rewolucja ta skierowała się przeciw społecznej „opresji” w dziedzinie seksualności, zastanym podziałom na role społeczne, przeciw segregacji rasowej. Wrogiem rewolucji były wszelkie formy „autorytarności”: czy to w rodzinie (w relacjach między partnerami oraz rodzicami i dziećmi), miejscu pracy, polityce bądź nawet w szkole. Rewolucja skierowała swoje ostrze przeciw wszelkim formom podporzadkowania prawa jednej tylko moralności: prawo ma nie uprzywilejowywać żadnej etyki ${ }^{26}$. W jej wyniku jednostka uzyskała prawo do tego, aby mogła samodzielnie wyznaczać swoją rolę społeczna i akceptowane przez siebie zasady moralne oraz osobiście określać sens swojego życia. Lech Morawski opisuje ten proces następujaco:

Obywatele wyposażeni w szeroki i stale się zwiększający się zakres praw i wolności, a przy tym coraz bardziej wykształceni i niezależni od ze-

\footnotetext{
${ }^{24} \mathrm{~K}$. Obuchowski, Rewolucja podmiotu i nowy indywidualizm, w: Humanistyka przełomu wieków, red. J. Kozielecki, Wydawnictwo Akademickie Żak, Warszawa 1999, s. 131, 134.

25 Należy tu wspomnieć o ruchach praw obywatelskich, ekologicznych, antysegregacyjnych i feministycznych, które powstały w latach sześćdziesiątych ubiegłego wieku. Zob. L. Morawski, Główne problemy współczesnej filozofii prawa. Prawo w toku przemian, Wydawnictwa Prawnicze PWN, Warszawa 2000, s. 22 i nast.

${ }^{26}$ Jacek Bartyzel wskazuje na to, że obecnie najbardziej rozpowszechniona postacia liberalizmu moralno-obyczajowego jest permisywizm, czyli „postawa przyzwolenia na każdy sposób "samorealizacji», jaki tylko zostanie przez kogokolwiek ogłoszony”. Permisywizm jest „wykwitem długiej ewolucji znaczenia dwóch kardynalnych idei liberalizmu: wolności i tolerancji; w wypadku pierwszej - od wolności (liberty) od arbitralnego przymusu i bezprawia do "wyzwolenia" (liberation) z "opresywnych" struktur władzy, takich jak "autorytarna" rodzina, religia, normy moralne i obyczajowe; w wypadku drugiej - od tolerancji "negatywnej" (toleration), nawołującej do pokojowego współistnienia ludzi wyznających odmienne poglądy w różnych kwestiach, do (podniesionej do rangi cnoty samoistnej i głównej) tolerancji "pozytywnej" (tolerance), oznaczającej przymus afirmacji i równowartościowania każdego poglądu, czyli faktycznie "tolerancji represywnej" wobec "nietolerancyjnych", która zyskała sobie nazwę "politycznej poprawności" (political correctness)". J. Bartyzel, W gąszczu liberalizmów. Próba periodyzacji i klasyfikacji, Fundacja Servire Veritati, Instytut Edukacji Narodowej, Lublin 2004, s. 60-61.
} 
wnętrznych autorytetów, znajduja coraz mniej argumentów, by respektować prawo $z$ tego tylko powodu, że jest ono prawem. [...] Trafnie przy tym podkreśla się przechodzenie społeczeństw rozwiniętych od etyk heteronomicznych, sięgających do zewnętrznego i jednoczacego autorytetu (religia, Kościół), do etyk autonomicznych, w których jednostka żyjąca w świecie wielu różnych moralności i religii sama dokonuje wyboru moralności, według której chce żyć. Ma więc chyba rację $Z$. Bauman, gdy mówi, że w społeczeństwach postmodernistycznych, w których moralność jest w dużym stopniu kwestia wyboru, etyka staje się etyka bez kodeksów (morality without ethical code) i bez zasad ustalonych raz na zawsze (unprincipled morality). Sceptycyzmowi co do możliwości regulacyjnych moralności w sprawach jednostkowych towarzyszy sceptycyzm co do możliwości regulacyjnych moralności w sprawach systemowych ${ }^{27}$.

Idea autonomii sprowadza się zatem w dużym stopniu do odrzucenia właściwego dla cywilizacji agrarnych wyobrażenia natury i prawa natury jako heteronomicznego, bo stworzonego przez Boga (bogów). Od czasów epoki oświecenia człowiek dąży do tego, aby to on był podmiotem historii; historii, która „Bóg urządza człowiekow"28 ma więcej już nie być. Nigdzie indziej idea totalnej emancypacji nie został wyrażona tak radykalnie jak u Karola Marksa. Ze względu na jej aktualność warto przytoczyć dłuższy fragment jego Rękopisów ekonomiczno-filozoficznych:

Istota uważa się za samodzielna dopiero wtedy, gdy stoi na własnych nogach, a stoi na własnych nogach dopiero wtedy, gdy swoje istnienie zawdzięcza samej sobie. Człowiek, który żyje $z$ łaski innego, uważa się za istotę zależną. Żyję zaś całkowicie $z$ laski innego wtedy, gdy zawdzięczam mu nie tylko utrzymanie swego życia, lecz i to, że ponadto stworzył moje Życie, że jest źródłem mojego życia, a moje życie ma $z$ konieczności taka przyczynę zewnętrzna, jeśli nie jest moim własnym tworem. Dlatego akt stworzenia jest wyobrażeniem, które bardzo trudno wyprzeć ze świadomości ludu. Byt sam przez się przyrody i człowieka jest dlań niepojęty, ponieważ przeczy wszelkim oczywistościom życia praktycznego. [...] Skoro jednak dla człowieka socjalistycznego cała tak zwana historia powszechna jest niczym innym, jak tylko tworzeniem człowieka przez

${ }^{27}$ L. Morawski, Główne problemy..., s. 31-32.

${ }^{28}$ R. Koselleck, Vergangene Zukunft. Zur Semantik geschichtlicher Zeiten, Suhrkamp, Frankfurt am Main 1979, s. 263. 
pracę ludzka, jak tylko stawaniem się przyrody dla człowieka, to ma on oczywisty, nieodparty dowód swego narodzenia $z$ siebie samego, dowód procesu swego powstawania. Skoro istotność człowieka i przyrody stała się czymś praktycznym, zmysłowym, naocznym, skoro człowiek stał się dla człowieka praktycznie, zmysłowo, naocznie bytem przyrody, a przyroda dla człowieka bytem człowieka, pytanie o obca istotę, o istotę istniejaca ponad przyroda i człowiekiem - pytanie, które zawiera w sobie stwierdzenie nieistotności przyrody i człowieka - stało się praktycznie niemożliwe ${ }^{29}$.

Przytoczona wypowiedź Marksa nabiera wyrazistego znaczenia $\mathrm{w}$ świetle opisu procesu transformacji, którego dostarcza nam Sieferle. Zmiana reżimu socjometabolicznego na ten oparty na paliwach kopalnych dała człowiekowi olbrzymie możliwości kształtowania własnego otoczenia w sposób bliski filozoficznym marzeniom o ludzkiej autonomii ${ }^{30}$.

\section{Rewolucja genderowa a autonomia radykalna}

Fragment wypowiedzi Karola Marksa został tutaj przytoczony także po to, aby stanowił tło dla kwestii rewolucji genderowej ${ }^{31}$. $\mathrm{Na}$ marginesie warto zauważyć, że terminem „rewolucja genderowa” posługują się głównie jej krytycy. Zwolennicy przebudowy świata $\mathrm{w}$ duchu urzeczywistnienia ideału radykalnej autonomii $\mathrm{w}$ zasadzie nie odwołuja się już do pojęcia rewolucji, co nie zmienia faktu, że bez wątpienia chodzi tutaj o rewolucję.

\footnotetext{
${ }^{29}$ K. Marks, Rękopisy ekonomiczno-filozoficzne [z 1844 r.], wersja elektroniczna: Polska Sekcja MIA https://www.marxists.org/polski/marks-engels/1844/rekopisy/rekopisy.htm\#R07 [dostęp: luty 2018].

${ }^{30}$ Nie bez powodu Sieferle poświęcił Marksowi jedna ze swoich monografii: R.P. Sieferle, Die Revolution in der Theorie von Karl Marx, Ullstein Buch, Frankfurt - Berlin - Wien 1979. Uważał bowiem, że Marks był jednym z pierwszych myślicieli, którzy zrozumieli, jak radykalna zmianą była industrializacja, której sam był świadkiem.

${ }^{31}$ Wystarczy spojrzeć na tytuły książek wydawanych przez katolickich przeciwników nurtu genderowego: G. Kuby, Rewolucja genderowa: nowa ideologia seksualności, przeł. M. Urban, D. Jankowska, Wydawnictwo Homo Dei, Kraków 2007; Rewolucja genderowa, red. Z. Klafka, Wyższa Szkoła Kultury Społecznej i Medialnej, Toruń 2014. O rewolucji genderowej pisze także M.A. Peeters, Gender - światowa norma polityczna i kulturowa: narzędzie rozeznania, przeł. L. Woroniecki, Wydawnictwo Sióstr Loretanek, Warszawa 2013, s. 37 i nast.
} 
Radykalne teorie genderowe oraz queer neguja tak zwane esencjalistyczne podejście do kwestii definiowania płci oraz tożsamości płciowej i stoja na gruncie radykalnego konstruktywizmu społecznego $^{32}$. Według tych teorii binarny biologiczny podział na dwie płcie jest reprodukowany $\mathrm{w}$ społeczeństwie przez praktyki społeczne, które zmuszają ludzi do tego, aby ciagle definiowali się jako przynależni do jednej $z$ dwóch płci $^{33}$. Zwolennicy owych teorii postrzegaja to jako element hegemonii kulturowej, której przeciwstawiają żądanie pluralizmu w kwestii tego, jak człowiek ma określać swoją tożsamość płciowa ${ }^{34}$. Teorie te postulują zatem prawo do swobodnego i dobrowolnego wyboru różnorodnych tożsamości płciowych, należących do zbioru wirtualnie nieskończonej liczby takich tożsamości ${ }^{35}$. Ograniczeniem tego prawa jest „nadbudowa kulturowa” zbudowana w oparciu o normatywność binarna kobieta/mężczyzna. Dekonstrukcja heteroseksualności jako normy panującej ma otworzyć człowiekowi drogę do pełnej emancypacji.

Istota rewolucji genderowej jest więc zanegowanie przekonania, że tożsamość płciowa - czy też orientacja seksualna człowieka - sa determinowane przez obiektywne czynniki biologiczne, czyli naturalne. Wpisuje się ona zatem w Marksowska koncepcje „istoty samodzielnej”. Władza człowieka nad natura - a przynajmniej władza kulturowa - ma sięgać tak daleko, aby człowiek mógł odrzucić także to, że o jego tożsamości płciowej ma decydować biologia, czyli reguły heteronomiczne. Człowiek ma się stwarzać sam, co konkretnie oznacza, że sam ma również stwarzać swoją samoświadomość i tożsamość. Ma to obejmować również samoświadomość istoty „stworzonej” także pod względem jej tożsamości płciowej.

\footnotetext{
${ }^{32}$ Zob. hasła: gender, queer, esencjalizm, konstruktywizm społeczny, w: Encyklopedia gender. Płeć $w$ kulturze, red. M. Rudaś-Grodzka i in., Wydawnictwo Czarna Owca, Warszawa 2014.

${ }^{33}$ J. Marchbank, G. Letherby, Introduction to Gender: Social Science Perspectives, Pearson Longman, Harlow [etc.] 2007, s. 5.

${ }^{34}$ Ibidem, s. 9.

${ }^{35}$ M.A. Peeters, Gender..., s. 69.
} 
Rewolucja genderowa stanowi zatem radykalny etap procesu transformacji, w którym zostały rozerwane zwiazki ludzkiej samoświadomości i biologii w sferze, która wcześniej wydawała się niemożliwa do „ruszenia $z$ posad”.

\section{„Kryzys ludzkiej natury”}

\section{Model oeconomia naturae}

Pierwsi liberalni reformatorzy i inżynierowie społeczni tkwili mentalnie $\mathrm{w}$ wyobrażeniach świata oświeceniowego $z$ jego wiara w „naturalna harmonię” oraz „naturalny porządek” świata ludzi wolnych i rozumnych. Peter Sieferle wskazuje na to, że liberalizm opierał się na wyobrażeniu rzeczywistości jako harmonijnym porządku naturalnym, ściśle zwiąanym $z$ deistycznymi poglądami religijnymi wielu myślicieli epoki oświecenia ${ }^{36}$. Najpóźniej w XVIII wieku model ten zastapił model wcześniejszy, natura lapsa. Ów nowy model został nazwany przez Sieferlego mianem oeconomia naturae. Opierał się on na deistycznym obrazie świata, według którego natura - jako przyroda oraz jako świat ludzki - działa spontanicznie, zgodnie $z$ odwiecznymi prawami, i to $z$ precyzja zegar$\mathrm{ka}^{37}$. Sieferle mówi w tym kontekście o naturalnej teleologii, która jest charakterystyczna dla tego modelu ${ }^{38}$. W modelu oeconomia naturae harmonia jest traktowana jako naturalny porzadek wyłaniajacy się ze spontanicznego działania poszczególnych elementów stworzenia. Elementy te nie muszą w sposób intencjonalny działać na rzecz dobra całości - wystarczy, że poruszaja się po torach, które sa zasadami stworzonymi przez Boga ${ }^{39}$. Bóg nie musi więc prowadzić każdego poszczególnego stworzenia $z$ osobna, wystar-

\footnotetext{
${ }^{36}$ R.P. Sieferle, Die Krise der menschlichen Natur..., s. 14 i nast.

${ }^{37}$ Ibidem, s. 24 i nast.

${ }^{38}$ Ibidem, s. 25.

${ }^{39}$ Ibidem, s. 30.
} 
czy, że nada naturze doskonałe prawa, tak że ze spontanicznych działań poszczególnych aktorów wyłoni się porządek, który będzie służył realizacji wyższych celów. Model ten charakteryzuje się zatem wyobrażeniem wewnętrznego porządku i regularności przyrody, jej spontanicznej samoregulacji, które zostaje przenoszone na sferę moralności, ekonomii i polityki ${ }^{40}$. Koncepcja spontanicznej samoregulacji natury i społeczeństwa leży u podstaw liberalnej teorii społecznej Adama Smitha.

Porządek społeczny epoki transformacji był więc od początku odgórnie zaprojektowany i zaplanowany przez człowieka ${ }^{41}$. Cecha charakterystyczna tego nowego porzadku było stworzenie takich instytucji prawnych, które umożliwiały społeczną mobilizację, a tym samym przejście od zasady statyczności do zasady dynamizmu. Nowy liberalny porządek społeczny zakładał, że każdemu zostanie przypisana określona sfera wolności, co uwolni ludzka przedsiębiorczość, kreatywność czy też po prostu energię. Dzięki temu, że każdy zacznie aktywnie „szukać swego”, gospodarka będzie się gwałtownie rozwijać. Temu właśnie miało służyć wprowadzenie nowych liberalnych instytucji prawa prywatnego, takich jak wolność zawierania umów, wolność testowania, wolność obrotu ziemia, wolność podejmowania działalności gospodarczej, wolność wyboru zawodu. Podstawa filozoficzna tych instytucji były koncepcje oświeceniowe, zgodnie $z$ którymi każdy miał naturalne - w znaczeniu wypływające $z$ oświeceniowych koncepcji prawa natury - uprawnienia do samodzielnego decydowania o sobie.

Sieferle podkreśla, że dla koncepcji liberalnych opartych na modelu oeconomia naturae charakterystyczne było poczucie bezpieczeństwa i zaufania w siły naturalnego porządku. Skoro wszechpotężny Bóg stworzył doskonałe prawa natury, to jeśli człowiek

\footnotetext{
${ }^{40}$ Ibidem, s. 32.

${ }^{41}$ F. Böhm, Die Ordnung der Wirtschaft als geschichtliche Aufgabe und rechtsschöpferische Leistung, W. Kohlhammer, Stuttgart - Berlin 1937, s. 42; idem, Freiheit in Ordnung in der Marktwirtschaft, rozdział Privatrechtgesellschaft und Marktwirtschaft, Nomos, Baden-Baden 1980, s. 105-168; idem, Wettbewerb und Monopolkampf, Nomos, Baden-Baden 2010, s. 129 i nast.
} 
swoim rozumem je odkryje i będzie naśladował, to nic złego stać się nie może. Na gruncie tak pojmowanej teleologii naturalnej nie do pomyślenia było wyobrażenie możliwości na przykład katastrofy ekologicznej42. Model ten znajdował też długo potwierdzenie w realnych procesach społecznych - człowiek tworzył coraz to nowe wynalazki, coraz więcej produkował, nawet problem proletaryzacji społeczeństwa wydawał się z czasem rozwiąywalny, gdyż ogólny poziom zamożności społeczeństwa rósł. Dopiero w połowie $\mathrm{XX}$ wieku wiara człowieka $\mathrm{w}$ naturalna harmonię ostatecznie się załamała.

\section{Śmierć Boga a obraz natury}

Sieferle wskazuje, że od czasów pojawienia się teorii Darwina obraz świata jako perfekcyjnego dzieła Bożego był poddawany coraz większej erozji. Wraz $z$ ogłoszeniem „śmierci Boga” przez Nietzschego model oeconomia naturae jako element oeconomia divina ostatecznie przeszedł do historii ${ }^{43}$. Wiara w naturalna harmonię i naturalny porządek się załamała. Pojawiło się przekonanie, że spontaniczne działanie ludzkie wytwarza często dysharmonię, nieporządek i chaos, co może prowadzić do samozniszczenia społeczeństwa czy też nawet człowieka jako gatunku. Wskutek tego musiało dojść do „przewartościowania wszystkich wartości” i człowiek musiał sam zastapić miejsce pozostałe po „umarłym Bogu”. To, co zostało uznane za niezdolne do działania siła własnych wewnętrznych prawidłowości musiało być kierowane przez nowa instancję - państwową interwencję i planowanie ${ }^{44}$.

Sieferle tutaj właśnie upatruje źródeł socjalizmu, który całkowicie odrzucił wiarę w możliwość oddolnej, spontanicznej samoregulacji społecznej. W jego opinii esencja socjalistycznego światopogladu jest przekonanie, że skoro nie ma żadnej instancji, która czuwa

${ }^{42}$ R.P. Sieferle, Die Krise der menschlichen Natur..., s. 33.

${ }^{43}$ Ibidem, s. 193.

${ }^{44}$ Ibidem, s. 195. 
nad tym, aby świat się harmonijnie rozwijał, człowiek od początku do końca musi wziąć sprawy w swoje ręce i o wszystko zadbać sam. Człowiek - czyli państwo, ponoszące totalną odpowiedzialność za całe życie społeczne ${ }^{45}$.

Podstawa światopoglądu socjalistycznego według Sieferlego jest zatem odrzucenie jakiekolwiek pojęcia natury w znaczeniu normatywnym. Natura sama w sobie nie ma wewnętrznego ładu i harmonii, do których człowiek powinien się dostosować. To człowiek, poprzez swoje prawodawstwo i totalna odpowiedzialność, ma uchronić naturę - i siebie jako część natury - przed samozniszczeniem.

Wychodząc poza obszar rozważań samego Sieferlego, na marginesie można stwierdzić, że to, co opisuje on jako światopogląd socjalistyczny jest charakterystyczne dla całego nurtu światopoglądowo-ideologicznego związanego ze współczesna socjaldemokracją czy też środowiskami, które same siebie określaja jako progresywistyczne ${ }^{46}$. Immanentna cecha tego nurtu jest przekonanie o istnieniu dwóch faz modernizacji. Pierwsza charakteryzowała się optymizmem i wiara w możliwość pełnego opanowania natury przez człowieka, druga natomiast to permanentne zarzadzanie kryzysem $^{47}$. Ze względu na materialistyczny charakter tego światopoglądu, czyli odrzucenie tezy o istnieniu Transcendencji, która ponosi totalna odpowiedzialność za świat, odpowiedzialność tę ponosi człowiek $^{48}$. Przedstawicielami tego nurtu sa między innymi znany niemiecki socjolog Ulrich Beck czy też brytyjski politolog David Held. Beck jest autorem koncepcji społeczeństwa ryzyka oraz pro-

\footnotetext{
45 Ibidem, s. 197.

${ }^{46} \mathrm{~W}$ tym kontekście należy wymienić takie międzynarodowe organizacje jak: The Spinelli Group, The Progressive Alliance of Socialists and Democrats (S\&D), The Progressive Alliance (PA), The Socialist International (SI), Foundation for European Progressive Studies (FEPS). $\mathrm{Na}$ temat progresywizmu zob. J. Fonte, Liberal Democracy vs. Transnational Progressivism. The Future of the Ideological Civil War within the West, „Orbis” 2002, Summer, b.n.s.

${ }^{47}$ Por. np. U. Beck, A. Giddens, L. Scott, Reflexive Modernization. Politics, Tradition and Aesthetics in the Modern Social Order, Polity Press, Cambridge 1994; U. Beck, E. Grande, Varieties of Second Modernity: The Cosmopolitan Turn in Social and Political Theory and Research, „The British Journal of Sociology” 2010, t. 61, nr 3, s. 409-443.

${ }^{48}$ Por. T. Ślipko, Bioetyka. Najważniejsze problemy, Wydawnictwo Petrus, Kraków 2009, s. 33 i nast.
} 
pagatorem idei kosmopolityzmu ${ }^{49}$. Held natomiast wychodzi $z$ podobnych przesłanek jak Beck - czyli wskazuje na istnienie globalnych problemów związanych $z$ kryzysem ekologicznym, socjalnym, ekologicznym itd. - i propaguje utworzenie socjaldemokratycznych struktur globalnego governance ${ }^{50}$. Obydwaj autorzy zostali wspomniani po to, aby pokazać, że analiza Sieferlego bynajmniej nie odnosi się wyłącznie do wcześniejszych nurtów socjalistycznych, które politycznie odeszły już do lamusa, ale znajduje zastosowanie do zupełnie aktualnych nurtów światopoglądowych i ideologicznych ${ }^{51}$.

Problematyka kryzysu ekologicznego zajmuje bardzo ważne miejsce w twórczości Sieferlego. Poświęcona jej jest między innymi praca zatytułowana Kryzys ludzkiej natury ${ }^{52}$. Sieferle wskazuje $\mathrm{w}$ niej na to, że w procesie transformacji człowiek uzyskał tak daleko posuniętą władzę nad naturą, że jest w stanie unicestwić samego siebie. Dla ludzi żyjących w pierwszej połowie XX wieku sama możliwość tego, by człowiek mógł zniszczyć niemal całą swoja planetę, była po prostu nie do pomyślenia ${ }^{53}$.

Sieferle wskazuje, że człowiek u progu procesu transformacji zachwycił się wizją naśladowania Stwórcy po to, aby wraz z pojawieniem się między innymi darwinizmu odrzucić ideę Stwórcy i postawić się na jego miejsce, tak jak to postulował między innymi

\footnotetext{
${ }_{49}$ Por. np. U. Beck, Risikogesellschaft, Suhrkamp, Frankfurt am Main 1986; idem, The Cosmopolitan Society and Its Enemies, „Theory, Culture \& Society” 2002, t. 19, nr 1-2, s. 17-44; idem, Cosmopolitan Vision, Polity Press, Cambridge 2006; idem, E. Grande, Cosmopolitan Europe, Polity Press, Cambridge 2007.

${ }^{50}$ Por. np. D. Held, Democracy and the Global Order: From the Modern State to Cosmopolitan Governance, Stanford University Press, Stanford 1995; D. Held, Global Covenant: The Social Democratic Alternative to the Washington Consensus, Polity Press, Cambridge 2004.

${ }^{51}$ Więcej na temat technokratycznego oblicza współczesnego państwa zob. np. M. Ziętek, Między emancypacja a technokratyzmem: prawo $w$ służbie budowy Nowej Atlantydy?, w: Questiones de qualitate vitae, red. A. Wudarski, Akademia im. Jana Długosza, Frankfurt (Oder) - Częstochowa - Osnabrück 2014, s. 569-588; M. Ziętek, Europejskie prawo konsumenckie jako wyraz technokratycznej koncepcji prawa umów, w: Kierunki rozwoju europejskiego prawa prywatnego - wpływ europejskiego prawa konsumenckiego na prawo krajowe, red. M. Jagielska, E. Rott-Pietrzyk, A. Wiewiórowska, C.H. Beck Wydawnictwo Polska, Warszawa 2012 , s. 275-29.

${ }^{52}$ R.P. Sieferle, Die Krise der menschlichen Natur... .

${ }_{53}$ Podobnie H. Jonas, Das Prinzip Verantwortung. Versuch einer Ethik für die technologische Zivilisation, Suhrkamp, Frankfurt am Main 2003, s. 26 i nast.
} 
Marks. Obraz natury pozbawiony deistycznego elementu naturalnej teologii musiał się diametralnie zmienić w kierunku układu stochastycznego, który nie jest wprawdzie chaotyczny, ale jego stabilność ma charakter czasowy i relatywny ${ }^{54}$.

Dzięki mobilizacji paliw kopalnianych człowiek mógł zatem początkowo zupełnie podważyć obowiazywanie zasad zrównoważonego rozwoju i dążyć do nieograniczonej ekspansji na polu wykorzystania zasobów naturalnych i kształtowania swojego otoczenia. Wraz z postępami procesu transformacji optymizm ten ulegał coraz większemu załamaniu. Człowiek musiał w końcu przyzwyczaić się do stanu permanentnego kryzysu i, jak dotąd, jedyne, co mu pozostaje, to odgórne, planowe „zarządzanie kryzysem”.

\section{Kryzys ludzkiej natury a rewolucja genderowa}

Kryzys ekologiczny wydaje się potwierdzać wątpliwości tych, którzy uważaja, że człowiek podlega określonym zewnętrznym, naturalnym ograniczeniom. Pierwotny optymizm człowieka i wiara w jego moc „samostwarzania" się i podporząlkowywania sobie natury - tak bardzo widoczne na przykład u Marksa - zostały mocno nadszarpnięte. Co więcej, obecnie mamy do czynienia $z$ pojawieniem się nowego, biocentrycznego spojrzenia na naturę, które jest przeciwstawiane wcześniejszemu antropocentrycznemu paradygmatowi dominacji człowieka nad przyroda ${ }^{55}$. Paradygmat ten zrodził się w klimacie kultu życia i dążności do zachowania różnych jego form w określonych granicach, przy czym człowiek jest traktowany jako taka sama część natury jak inne byty biologiczne. Ontyczna kondycja świata zwierząt zostaje zrównana

\footnotetext{
${ }^{54}$ R.P. Sieferle, Die Krise der menschlichen Natur..., s. 194.

${ }^{55}$ T. Ślipko, Bioetyka..., s. 29 i nast. Zob. też M. Ziętek, Katholische und protestantische Ethik im Dialog. Der bioetische Imperativ von Fritz Jahr aus Sicht von Tadeusz Ślipko, w: Studien zur Ethik in Ostmitteleuropa, t. 15: 1926 - Die Geburt der Bioethik in Halle (Saale) durch den protestantischen Theologen Fritz Jahr (1895-1953), red. F. Steger, J.C. Joerden, M. Schochow, Peter Lang, Frankfurt (Main) 2014, 195-213.
} 
z kondycją człowieka ${ }^{56}$ - ludzka natura staje się wyłącznie natura biologiczną.

Biorąc pod uwage doświadczenia kryzysu ekologicznego, ale także kryzysu ekonomicznego czy też politycznego, w których pograżona jest Europa, należy zadać pytanie o przyszłość rewolucji genderowej. Bez wątpienia można stwierdzić, że znajduje się ona obecnie na pierwszym, „optymistycznym” etapie. Jej zwolennicy i realizatorzy wierza, że rewolucja ta przyniesie człowiekowi większą wolność oraz możliwość realizacji swojej autonomii. Patrząc jednak na przebieg poprzednich etapów rewolucji, można dojść do wniosku, że zasadność takiego optymizmu można podważyć. Istnieje bowiem poważne niebezpieczeństwo, że także i w tej kwestii rewolucja spowoduje kolejny kryzys. Tym razem będzie to jednak nie kryzys w środowisku zewnętrznym, politycznym czy gospodarczym otoczeniu społecznym człowieka, ale kryzys w obrębie samego człowieka, który dotknie jego psyche.

Jedno jednak jest pewne. Mimo potencjalnego zagrożenia kolejnym kryzysem oraz doświadczenia wszystkich minionych i obecnych kryzysów człowiek zabarykadował sobie drogę powrotu do świata cywilizacji agrarnych i panujacych w nich przekonań na temat tego, co jest „naturalne”. Po pierwsze, świat cywilizacji agrarnych rozwinał się w sposób ewolucyjny i nie da się go stworzyć „odgórnie”. Po drugie, ludzka samoświadomość przė̇yła głęboki proces „odczarowania” świata i dawne formy samoświadomości stały się jej skrajnie obce. Należy zatem wskazać na to, że proces transformacji trwa dopiero około dwustu lat, a poprzednie epoki potrzebowały stuleci, aby wykrystalizować swoją ostateczna postać. I być może człowiek musi po prostu skonfrontować się $z$ tragicznymi skutkami własnej „autonomii” po to, aby dowiedział się czegoś więcej na temat tego, co rzeczywiście jest naturalne, a co nie wynika jedynie $z$ ewolucyjnie wykrystalizowanych ludzkich przekonań i ludzkiej samoświadomości. I być może w koń-

56 Ibidem, s. 32. 
cu proces transformacji przestanie być wyłącznie transformacją, ale wyłoni się $z$ niego pozytywny wzorzec nowej cywilizacji, której kształtu na razie nie znamy $^{57}$.

\section{Sex travelling into the unknown: Reflections on the margins of Rolf Peter Sieferle's modernisation theory}

The basis for considering the problem of the 'gender revolution' is the historiosophical concept developed by Rolf Peter Sieferle, who assumes that for about 200 years, Europe has been evolving from agrarian civilisation towards a new type of energy based on fossil fuels. A characteristic feature of this transformation process is the belief that man is the 'master of forms' - all elements of the earlier order, which were perceived as natural for generations, have been questioned. The revolution overthrew the existing hierarchical feudal order, created factories, the bourgeoisie and the proletariat in order to create a mass society, a welfare state and, finally, a progressive agenda. The revolutionary process also affected social roles, leading to women's emancipation movements. At the current stage of the revolution, the natural division into two sexes has been questioned. The basic question is whether a person can really deny the idea of the natural order in such a fundamental way? The ecological crisis, caused by the first phase of the revolution, seems to confirm the doubts of those who believe that human beings are subject to external, natural limitations.

Keywords: Rolf Peter Sieferle, modernisation, transformation, gender revolution, human nature.

\footnotetext{
${ }^{57}$ Warto zwrócić uwagę na to, że w końcu sam młody Marks nie wiedział, jak ma wyglądać ostateczne stadium rozwoju ludzkości: „Komunizm jako zaprzeczenie zaprzeczenia jest pozytywnym stanowieniem i dlatego jest rzeczywistym, koniecznym dla najbliższego etapu rozwoju historycznego, momentem emancypacji i odnalezienia się człowieka. Komunizm jest konieczną formą i czynna zasadą najbliższej przyszłości, ale komunizm nie jest jako taki celem rozwoju ludzkiego - formą społeczeństwa ludzkiego”. K. Marks, Rękopisy... .
} 